\title{
Legality of Child Marriage in Nigeria and Inhibitions Against Realisation of Education Rights
}

\author{
Kayode Olatunbosun Fayokun \\ Obafemi Awolowo University, Ile-Ife, Nigeria
}

\begin{abstract}
Early marriage forces girls into adulthood before they are emotionally and physically matured, leading to a range of harmful effects on their health, education, and economic and social development. For many countries, 18 is the legal age of marriage. Nigeria has undergone fierce constitutional battles to establish a minimum age for marriage. This paper examines the controversies surrounding the legality of child marriage conducted in Nigeria. The paper observed the high prevalence of child marriage among the Hausa-Fulani communities in Northwest Nigeria in spite of international and domestic legal instruments outlawing child marriage. It also observed that child marriage in those communities is predicated on Islamic marital jurisprudence. The paper found loopholes in the law as the major rift lines in the conflict of laws of marriage in Nigeria. It suggests a harmonisation of laws and improved education for girls to strengthen the prioritisation of policy against child marriage.
\end{abstract}

Keywords: child marriage, children's rights, education rights

\section{Introduction}

Child marriage is seen as a fundamental violation of human rights (United Nations International Children's Emergency Fund (UNICEF), 2014; International Center for Research on Women, n.d.; UNICEF, 2012). Several surveys show that many young girls are married without their free and full consent (Girls Not Brides $^{1}$, n.d.; Population Council, 1995; 2004). The health and education of women are key factors in the realisation of at least six of the Millennium Development Goals (MDGs) ${ }^{2}$. Olasode, Olaogun, Fatusi, and Mosaku (2008), for example, contended that women's health is the bulwark of the family and the foundation for social and community progress. Child marriage means increased health risks for young girls (Anthony, 2013; UNICEF, 2001). Child marriage is also closely associated with no or low levels of schooling as surveys

Kayode Olatunbosun Fayokun, Ph.D., senior lecturer, Department of Business Law, Faculty of Law, Obafemi Awolowo University.

${ }^{1}$ Many Civil Society Organizations (CSOs) like Girls Not Brides are dedicated to stopping child marriage and other violations of children rights around the world. A coalition of such CSOs in Nigeria include Action Aid, Adolescent Health \& Information Projects (AHIP), Advocacy Nigeria, African Child Education Right Initiatives, Alliances for Africa, Arise Nigerian Women, Centre for Religious Cooperation and Tolerance, Community Action for Popular Participation (CAPP), David Bassey Ikpeme Foundation, Dynamic Youth Development Organisation (DYDO), El-Saddai Rural Health \& Development Foundation, Girl Child Concerns, Global Improvement of Less Privilege Persons, Good Living Initiative, Grassroots Health Organisation of Nigeria, Haliru Youth Development and Employment (AYIDI), Isa Wali Empowerment Initiative Intervention (IWEI), Life foundation, Women United for Economic Empowerment, and Women's Aid Collective (WACOL).

2 "Child, early and forced marriage have hindered advancement of six of the eight MDGs. The six MDGs are: eradicate extreme poverty and hunger; universal primary education; gender equality; child mortality; maternal health; combat HIV and other diseases" (Statement credited to the Canadian High Commissioner in Nigeria, Mr. Perry Calderwood in "Canada, Nigerian NGO partner to end child marriage". Retrieved from http://www.punching.com/news/canada-nigeria-ngo-partner-to-end-childmarriage). 
show that girls with three or fewer years of schooling are five times more likely than girls with eight or more years of schooling to marry before age 18 (Population Council, 2004).

In the global struggle that has highlighted the plight of uneducated girls in poor countries as most vulnerable, Nigeria holds the world's record with the most children out of school. The staggering number is above 10,000,000 (Oduah, 2013). Throughout her entire life circle, a girl's daily existence and long-term aspirations are restricted by discriminatory attitudes. Unjust social and economic structures have ensured from childhood to adulthood that she never actualises her potentials. Of the over 1,000,000,000 of people living in unacceptable conditions of poverty in the world today, the great majority are women in developing countries meaning the feminisation of poverty ${ }^{3}$. The plight of the girl child has gained currency in international fora, such as the World Summit for Children, New York, 1990 and the World Conference on the Education of Girls, Ouagadougou, 1993. At the Fourth World Conference on Women, Beijing, 1995, factors inhibiting the realisation of women's potentials or adverse to their health were addressed. Child marriage is recognised as one of the strongest social malaise which must be eradicated to improve on the quality of life of the girl child in the pursuit of sustainable development ${ }^{4}$ (United Nations Fund for Population Activities (UNFPA), 2012; UNICEF, 2013; Girls Not Brides, n.d.).

The case of Wasila (Tasi'u) Umar, the 14-year-old Nigerian child bride standing murder trial for killing her husband again raises the issue of the legality of child marriage in Nigeria. Wasila, 14, was given out in marriage to Umar Sani, 35, in Gezawa, outside the northern city of Kano in April, 2014. Seventeen days into the marriage, Wasila was accused of murdering Umar and three of his friends by food poisoning, at her own wedding party. She alleged that it was a forced marriage to a man she did not love and did not want to have a relationship with. Soon after she was arrested, Wasila told her lawyer Hussaina Ibrahim that she had been tied to the bed and raped by Sani on their wedding night. The Gewaza High Court rejected a motion to have murder charges against her quashed, ruling that the trial should proceed. She stands the risk of conviction and death penalty. Child marriage is a complex and controversial issue in Nigeria and may be viewed differently depending on the context. There are wide disparaging views of the subject based on cultural and religious differences, regional and ethnic disparities, as well as dichotomy of conflict of law issues.

\section{Cultural and Religious Norms}

Child marriage is rooted in the cultural traditions of the Hausa-Fulani communities in Northwest Nigeria. Child brides often come from patriarchal societies where parents and elders play very significant or domineering roles in selecting spouses for their children. Strong cultural norms place emphasis on a girl's virginity, which is closely tied to a family honour. Parents are disposed to marrying off their daughters at a very tender age to ensure they marry as virgins and retain the family honour. The practice of child marriage is also strongly followed as a way of protecting the girl child from sexual assault and unwanted out-of-wedlock pregnancies.

The prevalence of child marriage in Hausa-Fulani communities in Northwest Nigeria also lies along

\footnotetext{
${ }^{3}$ Barbere Conable, President of the World bank Group (1984-1991) at an Annual General Meeting of the World Bank and IMF, as cited in Olasode et al. (2008).

${ }_{4}$ According to statistics presented by the former Central Bank Governor, Lamido Sanusi, as many as $93 \%$ of female children in the northwest region of Nigeria are being denied access to secondary education; 70\% of women between age 20-29 in the northwest region are unable to read, compared with $9.7 \%$ in the southwest.
} 
religious lines. Most child brides are from Mohammedan homes. To a large extent, the marriage culture is dictated by Islamic religious norms. Prepubescent marriage is the norm. The man is said to promise not to touch the girl until she reaches puberty and that this practice is in line with Prophet Mohammed's marriage to Aisha

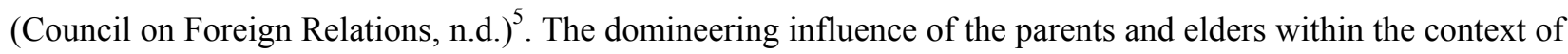
strong religious norms based on an interpretation of Islamic marital code fuels the belief that a girl child is fully matured for marriage and should be married off before or upon reaching puberty, the sure sign of which is the commencement of the menstrual period. It is believed that early marriage for a girl child maximizes her childbearing potential. Within that Islamic culture, the new bride is often absorbed into a large harem where she is confined to strictly domestic roles. As Islam has permeated the socio-cultural life of the Hausa-Fulani, so has Islamic law and jurisprudence become assimilated into the native law and custom especially on issues of personal law relating to marriage and family life.

\section{Who Is a Child?}

International legal norms prescribe age description of children. Childhood ends at age 18 . The consistent position in several international legal instruments including the Universal Declaration of Human Rights (UDHR) and the Convention on the Elimination of All Forms of Discrimination Against Women (CEDAW), is that girls of relatively tender age are most vulnerable persons in need of added legal protection. The language of these and other international instruments set a global standard for that protection worldwide.

There had been several international initiatives to prevent child marriage in this decade alone. In December 2011, a resolution was adopted by the United Nations General Assembly (A/RES/66/170) designating October 11 as the International Day of the Girl Child. On October 11, 2012, the first International Day of the Girl Child was held, the theme of which was ending child marriage. In 2013, the first United Nations Human Rights Council resolution against child, early, and forced marriages was adopted. The resolution recognises child marriage as a human rights violation and pledges to eliminate the practice as part of the United Nations' post-2015 global development agenda. In 2014, the United Nations' Commission on the Status of Women issued a document in which they agreed, among other things, to eliminate child marriage. All these underscore the UDHR that all "Human beings (including children) are born free and equal in dignity and rights" (United Nations, 1948, Article 1). For several decades, the UDHR has served as a vibrant moral conscience to the world community including Nigeria. It has provided international norms and standards to which the world community is expected to adhere.

The Convention on the Rights of the Child (CRC) was adopted by the United Nations in November, 1989. Nigeria ratified the CRC in March 1991. It is the most widely accepted instrument of the United Nations so far. Its provisions are not only binding on Nigeria but have also attained the status of international customary law. Article 1 defines a child as: "For the purposes of the present Convention, a child means every human being below the age of 18 years unless, under the law applicable to the child, majority is attainted earlier" (United Nations Human Rights, 1989, Article 1).

Thus, some view the CRC as setting a strong global age standard for marriage since children must be taken not matured enough for marriage. For others, the CRC with its imperfections, far from being a comprehensive treaty on children's rights, is a weak defensive legal mechanism for the protection of child

\footnotetext{
${ }^{5}$ Sani Ahmed Yerima, Nigeria Senator, said, "Islamic Law allows marriage not by age but by maturity, which is attained once a girl reaches the age of puberty".
} 
brides (Braimah, 2014).

The African Union Charter on the Rights and Welfare of the Child, of which Nigeria is a signatory, contains more explicit provisions. Article 2 states categorically that "For the purposes of this Charter, a child means every human being below the age of 18 years" (Organization of African Unity, 1999).

Article 21 goes on to say:

Child marriage and the betrothal of girls and boys shall be prohibited and effective action, including legislation, shall be taken to specify the minimum age of marriage to be18 years and make registration of all marriages in an official registry compulsory. (Organization of African Unity, 1999)

Article 3 provides that the "best interest of the child" shall be the primary consideration in all actions concerning the child. Moreover, the cumulative effect of Articles 1(3) and 21 is to render invalid customs, tradition, and cultural and religious practices that are injurious to the welfare, dignity, and normal growth and development of the child. Child marriage as practiced in northern Nigeria can indeed be invalidated under Articles 21(1)(a) as prejudicial or harmful to the health or life of the child bride.

After many years of lobby and debate, the CRC and African Children Charter were finally domesticated in Nigeria by the promulgation of the Child Rights Act (CRA) 2003. Section 21 of the CRA 2003 prohibits child marriage by stating that "No person under the age of 18 years is capable of contracting a valid marriage, and accordingly, a marriage so contracted is null and void of no effect whatsoever" (Policy and Legal Advocacy Centre, 2003, Part III).

For the avoidance of doubt, Section 22 states that: "(1) No parent, guardian or any other person shall betroth a child to any person; and (2) A betrothal in contravention of subsection (1) of this section is null and void" (Policy and Legal Advocacy Centre, 2003, Part III).

Moreover, Section 23 criminalises the practice of child marriage:

A person- (a) who married a child; (b) to whom a child is betrothed; (c) who promotes the marriage of a child; or (d) who betroths a child, commits an offence and is liable on conviction of a fine of 500,000 Naira or imprisonment for a term of five years or both such fine and imprisonment. (Policy and Legal Advocacy Centre, 2003, Part III)

Thus, in clear and unmistakable terms, the CRA 2003 prohibits and criminalises child marriage in Nigeria, though the law has not been effective in arresting the high incidence of child marriage among the Hausa-Fulani (Anthony, 2013; UNFPA, 2012; United Nations Population Fund, 2012; Ford Foundation, 2011).

\section{Why Child Marriage Persists in Nigeria}

The CRA 2003 having been in existence for over a decade, why does child marriage persist endlessly in Nigeria? Two seemingly insignificant loopholes in the Constitution of the Federal Republic of Nigeria (CFRN) 1999 are fingered as the legal obstacles against the eradication of child marriage. The first is Section 29(4), while the other is Item 61, Part 1 of the Second Schedule to the Constitution. Now, Section 29(1) permits a citizen of Nigeria of full age who wishes to renounce his citizenship to make a declaration in the prescribed manner. Section 29(4) states that "For the purposes of subsection (1) of this section: (a) 'Full age' means the age of eighteen years and above; and (b) Any woman who is married shall be deemed to be of full

\footnotetext{
${ }^{6}$ The latest research from UNICEF indicates (http://www.prb.org/pdf11/ending-child-marriage.pdf) that between 2007 and 2011 , the number of girls getting married before the age 15 increased by $5 \%$. The percentage managed to grow significantly despite the passing of the Child Rights Act (APA) Since 2003, which makes 18 the age of maturity and criminalises child marriage practices.
} 
age" (Federal Republic of Nigeria, 1999, Chapter III).

Having understandably been in the Constitution since 1979, a Senate committee in July, 2014 voted to remove the archaic "Part (b)" of the subsection, "thereby supporting the fight against forced marriage and paedophilia". However, after a heavy lobbying, Senator Sani Ahmed Yerima ${ }^{7}$ (the same man who at 49 had married a 13-year-old Egyptian girl) persuaded the Senate to reverse its decision, thereby retaining the obnoxious subsection and re-enacting a legal ground for child marriage.

The second loophole is tucked away in Item 61, Part 1, of the Second Schedule to the Constitution. In the "Exclusive Legislative List" of the Federal Government is an item: "61. The formation, annulment and dissolution of marriages other than marriages under Islamic law and Customary law including matrimonial causes relating thereto" (Federal Republic of Nigeria, 1999, Chapter V).

It effectively takes marriages under Islamic and Customary law out of the federal legislative competence. In other words, though the whole country is bound by federal law, in the strict sense, the laws of the National Assembly have no effect on the formation, amendment, and dissolution of marriages under Islamic law and customary law including matrimonial causes relating thereto. Thus, the surreptitious ineffectiveness and castration of the CRA has been perfected before it was promulgated. The CRA 2003 as a federal law cannot be implemented in a state until it has been domesticated as state law. As at today, only 24 out of the 36 states of the federation have gone ahead to domesticate the CRA as state law. Of the remaining 12 states, the CRA has in fact met with stiff resistance in some northern states where Islam has been accepted as a way of life and the Sharia law has been introduced. Unfortunately, these states are in the region ranked with the highest prevalence of child marriage in the world.

\section{Child Marriage and Internal Conflict of Law Issues}

The Nigerian legal system runs on three somewhat distinguishable streams of civil law, Islamic law, and customary law. For instance, marriages under customary law are not invalidated merely, because they do not meet the conditions stipulated for marriages under the Marriage Act, for they operate under different systems of law. Statutory provisions enjoin the High Courts to administer customary law along with law from other sources $^{8}$. In Oppion $v$ Ackinie $^{9}$, it was held that the continued exercise of the jurisdiction of customary courts was not inconsistent with that of the High Court but that both are "co-existent". Thus, marriages and matrimonial causes in customary law exist side by side with statutory marriages. The plurality of laws in the Nigerian legal system no doubt introduces a complexity which is bound to generate conflict of law problems. In the words of Niki Tobi:

Nigeria is a multilingua country with diverse varied and various ethnic groups, cultures and traditions. The sociology of the country is not only complex but highly diversified and heterogeneous. This type of society certainly gives rise to conflict problems in our laws, particularly when that highly diversified society operates a plurality of laws.

\footnotetext{
${ }^{7}$ Sani Ahmed Yerima, in the year 2000 as the then governor, had introduced full brown Islamic Sharia Code into Zamfara State. In the year 2000, Senator Yerima at 49 was alleged to have paid a 100,000 U.S. dollar dowry to marry a 13-year-old Egyptian girl at the national mosque in the capital city of Abuja. Yerima while defending his actions in a BBC interview denied breaking any law saying "I do not have to obey the Child Right Act so long it contravenes my religious beliefs". Newspaper reports claimed Yerima had earlier married a 15-year-old girl as third wife. Curiously no charges were passed against Yerima. An official of the Egyptian Embassy in Abuja, Mohammed Saber, was however of the opinion that marrying an underage girl is illegal in Egypt.

8 See for instance sections 12(1) and 26(1) of the High Court Law, Cap. 52, Laws of Lagos State, 1973. Similar provisions abound in the High Court Laws of other states.

9 15. (Unreported) (1887) Quoted in Niki Tobi, Sources of Nigerian Law (1996), MIJ Publisher, p. 8.
} 
Provisions like Item 61, Part 1, Second Schedule of the CFRN 1999 are a mere recognition of the diversity in the sociology of the country when it comes to cultural differences on marital issues. However, this has been blown beyond proportions in Nigeria. Those who exploit the loopholes push the provision into conflict with other sections of the Constitution. They sometimes harp on Section 38(1) of the Constitution which states that:

Every person shall be entitled to freedom of thought, conscience and religion, including freedom (either alone or in community with others, and in public or private) to manifest and propagate his religion or belief in worship, teaching practice and observance. (Federal Republic of Nigeria, 1999, Chapter IV)

Ishaq Akintola, director of Muslim Rights Concerns (MURIC), a non-government organisation, rising in defence of Yerima, had called on "tolerance" on the controversy concerning child marriage. Contending that freedom to engage in child marriage is part of the constitutional freedom of religion, he submitted that age was not part of the conditions which must be met before marriage could be solemnized in Islam, therefore, child marriage is in conformity with the tenets of Islam. One may however quickly debunk this line of thinking by juxtaposing Section 38 with Section 45 of the CFRN 1999. Of course, Section 45 provides inter alia:

(1) Nothing in Sections 37, 38, 39, 40, and 41 of this constitution shall invalidate any law that is reasonably justifiable in a democratic society:

(a) In the interest of defence, public safety, public order, public morality or public health;

(b) For the purpose of protecting the rights and freedom of the other persons. (Federal Republic of Nigeria, 1999, Chapter IV)

Thus, the counter-argument is that child marriage can justifiably be outlawed as a constitutional restraint on the freedom of religion, on the strength of Section 45. There is still a debate even within Islam about what age a girl reaches maturity. Many Muslim communities and Islamic scholars agree with the internationally recognised age of maturity which is 18 . Moreover, many Muslims argue against child marriage because they believe Islam mandates men and women to choose their partners voluntarily, and children are unable to do so.

\section{Child Marriage and Islamic Law}

Islamic law is now applied in Nigeria either as personal law or territorial law.

As personal law, Islamic law is treated as part of customary law applicable in those native communities where it has been assimilated into the corpus juris. In this context, Mohammedan law, according to Ames ${ }^{10}$, "has no privileged position in Nigeria. It prevails where it does prevail, because it is there the local law and custom". A rule of Islamic personal law that is inconsistent with a constitutional or statutory provision ought to be declared invalid or inapplicable without much ado in the courts in Nigeria. This, without much pretence, is the practice of the courts over the years.

Child marriage as practiced under Islamic personal law (a gross violation of children's rights) may easily be struck down under the validity tests prescribed for customary law. For instance, Section 26(1) of the High Court Law of Lagos State provides that:

The High Court shall observe and enforce the observance of every customary law which is applicable, and is not repugnant to natural justice, equity and good conscience nor incompatible either directly or by implication with any law for the time being in force.

${ }^{10}$ Bornu, N. A. v. Abatcha, M. (1946). Unreported, see Anderson (1969). 
Moreover, Section 18(3) of the Evidence Act states categorically that "In any judicial proceeding where any custom is relied upon, it shall not be enforced as law if it is contrary to public policy, or is not in accordance with natural justice, equity and good conscience".

Thus, were the legality of child marriage to be tested in the superior courts as a rule of Islamic personal law, it will fail the tests of validity. For instance, where a Muslim died intestate, it was held in Mallam Abba v Mary Baike ${ }^{11}$, that his Christian daughter cannot be disinherited under an Islamic rule of inheritance which prohibited non-Muslims from sharing from his estate. Ames held that the "exclusion of a Christian daughter from the inheritance of her father's estate was contrary to natural justice". Similarly, child marriage, weighed against the background of contemporary global sense of justice, if tested, will not only be held offensive to natural justice, equity, and good conscience, but is also obviously incompatible with existing statute law, or simply contrary to public policy.

The situation is however more problematic where Islamic law operates as territorial law. For example, the bill for the adoption of Sharia was passed by the Zamfara State House of Assembly into law in December, 1999. Some other core northern states followed suit, soon thereafter and have promulgated Sharia Code as state law. For those states, Islamic law presumably operates as full blown territorial law. It seems certain that under this new arrangement, it will be impossible to invoke the "repugnancy clause" for any rule under the Sharia legal code. In its authority and applicability as a forceful legislation the Sharia Code is not subject but will override rules of other sources of law. Consequently, we must fall back on the provisions of the Constitution as the only framework for testing the legality or validity of the rules of Sharia territorial law. A party wishing to resist the forceful rule of Sharia legal code may rely on enshrined constitutional rights which guarantee freedom of thought, conscience, and religion in order to strike down or determine the validity of those rules of Islamic law that are questionable under the Constitution. Section 10 of the Constitution clearly states that "The Government of the Federation or of a State shall not adopt any religion as State Religion" (Federal Republic of Nigeria, 1999, Chapter I, Part II). The continued practice of child marriage under Islamic law (a practice which flagrantly denies the girl child the exercise of her guaranteed rights to self determination) definitely comes into direct conflict with Sections 10, 38, and 42 of the Constitution and has to be challenged as such before the superior courts in Nigeria. In fact, the argument is strong that the enforcement of Sharia as territorial law in any constituent state of the Federation is discriminatory and unconstitutional.

\section{Consent in Marriage}

Another pertinent issue that affects the validity of child marriage is the consent of the parties to the marriage. It is submitted that there is no consent where the bride is incapable of understanding or appreciating the transaction or incapable of forming a rational opinion as to the union by reason of tenderness of age $\mathrm{e}^{12}$. The sad case of Wasila Umaru is very opposite here. Can it be said that it was Wasila Tasi'u, a 14-year-old bride, who was giving her consent to marry Sani Umar, a 35-year-old man, in the city of Kano when that marriage purportedly took place? This she later denied as against her wishes and consent and in expressing her utter disgust, killed her husband and his friends through food poisoning? Knowledge and consent are key and necessary elements for entering into a marriage contract and these can hardly be said to be present when a child

\footnotetext{
11 (Unreported) K/204/1943 cited in Anderson, Islamic Law in Africa, p. 16.

12 The Marriage Act requires a party to an intended marriage who is below 21 years to annex a written consent of his parent or guardian to his affidavit before a licence or certificate is issued. See Section 18 Marriage Act Laws of the Federation 2004.
} 
is given away to an adult much older than her age. Okafor (2014) subscribed to the view that in order to consent to something, you must be fully aware and have the capacity to understand what you are consenting to. Children lack this ability.

If one is to concede to the argument that autonomy and consent is key to a valid marital contract, then it is not hard to see why Wasila's marriage was both void and wrong (Okafor, 2014).

The right to "free and full" consent to a marriage is recognised in the UDHR and CEDAW prohibits forced marriage. Under the CRC, the government has committed itself to ensure the overall protection of children aged below 18. The CRA stipulates that the best interests of the child are to be of "primary consideration" in all actions concerning her. It is for this reason that Section 29(4) of Nigeria's 1999 Constitution is considered a setback in that it recognises a woman who is married to be of full age for the purpose of renouncing Nigerian citizenship. In other areas of the law, the minor is not accorded such capacity. She has no capacity to contract ${ }^{13}$. She cannot sue or be sued except through a next friend, a guardian ad litem, or a person in loco parentis. She cannot vote at the general elections nor obtain a driving licence. It is strange to the sensibilities of some that a person with such multiple disabilities is suddenly endowed with maturity under the Constitution irrespective of her age.

Islamic marital jurisprudence regulates the marriage contract (Nikah). In Islam, Nikah requires consenting partners. Though Islam encourages child marriage, it does not in theory encourage forced marriage, it annuls them, but in practice the "Yes" at the Nikah ceremony is hollow, a mere act of compliance, a formality that rarely translates into consent? This is what must be critically looked into. As a commentator observed:

\footnotetext{
... In many cases, those participating in the practice are given no other chance than to participate, which reduces their consent to mere formality. It is not a 14-year-old girl that is making the decision here. The decision is taken on behalf of her by the family, relatives or the community. (Ajumobi, 2014)
}

Ordinarily, no child should be robbed of her childhood, her health, her education, and ultimately her life aspirations on account of culture or circumstances of her birth.

\section{Child Marriage and Education Rights}

Education continues to be a strong indicator whether or not a girl will marry as a child in Nigeria. Screaming statistics reveal that virtually all married girls are out of school. UNICEF (2013) report show that $82 \%$ of women aged between 20 and 24 who have no education were married by the age of 18 , as opposed to $13 \%$ of women who have at least finished secondary education. Early marriage abruptly terminates any form of schooling and introduces the girl child to early sexual life, early motherhood with a myriad of health problems and a cycle of illiteracy and poverty. According to UNESCO reports, not only has Nigeria and sub-Saharan countries failed to achieve the 2015 "Education for All" (EFA) goals, indeed they are very far from achieving them. In the words of Kate Redman, "Nigeria now has more children out of school than when the global goals were set" (as cited in Eno-Abasi, 2015), and this is obviously traceable to a myriad of challenges inhibiting most especially the girl child (Eno-Abasi, 2015). Having realised that legislation alone may not adequately tackle the menace of child marriage, we must look for more effective means, capable of addressing beliefs rooted in the hearts of men.

Education, if harnessed from the prism of a fundamental human right as recognised in many domestic and

${ }^{13}$ See Lord Denning in Shephard v. Cartwright (1953) 2 All E.R. 608; G. (A) v G (T) (1970) 3 All E.R. 546. 
international legal instruments, can be an effective tool in tackling child marriage. Education rights are essential for the exercise of all other human rights. It has been established that education enhances individual freedom, provides empowerment, and promotes multiple developmental gains. Millions of young girls however remain deprived of educational opportunities as a result of early marriage. Statistics support the hypothesis that poverty, strong cultural norms, and low societal values for the girl child are the primary forces that fuel early marriage. Almost all child brides receive little or no schooling. Those who were in school immediately drop out after their marriage. UNICEF study shows clearly that high prevalence of child marriage is correlated with less education for girls. A shortened education is both a cause and effect of early marriage. From this perspective, child marriage is a gross violation of child rights and of course a great inhibition to the realisation of education rights. If the timing of marriage does not change, over 100,000,000 children will be married as children in the next 10 years (Council on Foreign Relations, n.d.). Thus, eradication of child marriage is an imperative for the actualisation of child education rights.

\section{Children's Right to Education}

Education is an essential right of an individual which permits a person to receive instruction and acquire knowledge for his economic and social well-being. Education for citizens in a country entails that its subjects acquire a variety of knowledge through access to schooling. It begins with the acquisition of elementary knowledge, i.e., literacy, on the part of the youngest member of the society. It follows with an essential schooling stage which permits the child to pursue his/her education by integrating secondary and post-secondary instruction.

Education is necessary for the development of a child's personality and identity as well as his/her physical and intellectual capabilities. It contributes immensely to the flourishing of the child's individuality through the enhancement of social and professional integration. Its ultimate objective is the improvement of the quality of life. It also offers the child the opportunity to escape from poverty and strong injurious cultures that are damaging to his/her health and that of others. It is thus an essential tool for personal and societal development.

Nigeria is bound by many international and domestic legal instruments on child's education rights. They assure that education is a human right which ought to be accessible to everyone without any discrimination. Article XXVI of the UDHR declares that "Everyone has the right to education". Similarly, Article XVII of the African Charter of Human and People's Rights also states that "Every individual shall have the right to education". The CRC enjoins state parties to recognize the right of the child to education and to "take measures to encourage regular attendance at school and the reduction of drop-out rates". As one of its fundamental objectives and directive principles of state policy, Section 18 of the 1999 Constitution states that government shall direct its policy towards ensuring that there are equal and adequate educational opportunities at all levels. In buttressing the education rights of the child, Section 15 of the CRA 2003 stipulates that every child has the right to free, compulsory, and universal basic education and it shall be the duty of the government in Nigeria to provide such education. In addition, every parent or guardian must ensure that his/her child or ward attends and completes both primary and junior secondary education. Thus, it is the responsibility of government and the duty of parents to guarantee each child's right to education. The point is that in countries where cultural and religious beliefs prevent equal access to education for boys and girls, there are hindrances to the actualization of education rights. The prevalence of child marriage especially in the northern part of Nigeria is a gross violation 
of the education rights of the girl child. Statistics have shown that the young bride usually quit school and contribute largely to the global illiteracy rate (Population Council, 2004).

\section{Conclusion and Recommendations}

The clear indicators are that child marriage is closely associated with no or low level of schooling for the girl child. A little delay in marriage for the girl child translates into longer years of schooling. The benefits of education include improved economic productivity. It is recommended first that there is a need to raise awareness of the benefits of educating the female child. There is also the need to raise awareness on the extent to which early marriages constitute gross human rights abuses on the part of the female child. The Constitution should be amended to jettison all archaic provisions and inject fresh provisions to keep it in line with developmental policies and global standards. State legislatures that have not done so must be persuaded to domesticate the CRA which outlaws child marriage. This will lead to the adoption of 18 as the legal age of marriage for girls in the predominantly Muslim states in Nigeria. Governments and communities are to be encouraged to commit to getting girls to school and to keep them in school at least through the secondary level. It has been shown that being in school during adolescence has important health and development benefits for girls. Implementation structures should also be embedded in the CRA including the development of non-formal education programmes, economic as well as social programmes for out-of-school girls.

\section{References}

Ajumobi, F. (2014). Nigeria and the ills of child marriages. Vanguard News Magazine. Retrieved April 13, 2015, from http://www.vanduardngr.com/2014/05/nigeria-ills-child-marriage

Anderson, J. N. D. (1969). Relationship between Islamic law and customary law in Africa. Journal of African Administration, $12(4), 228-234$.

Anthony, K. (2013). Child brides die young. Retrieved from http://allafrica.com/stories/201308050251.httml

Braimah, T. S. (2014). Child marriage in Northern Nigeria: Section 61 of Part 1 of the 1999 Constitution and the protection of children against marriage. African human Rights Law Journal, 14(2), 474-488.

Council on Foreign Relations. (n.d.). Child marriage: A CFR InfoGuide Presentation. Retrieved April 13, 2015, from http://www.cfr.org/peace-conflict-and-human-rights/child marriage/p3209\#!/

Eno-Abasi, S. (2015). Sub-Saharan Africa "very far" from achieving EFA goals, by UNESCO. The Guardian. Retrieved April 16, 2015, from http://www.ngrguardiannews.com

Federal Republic of Nigeria. (1999). Constitution of the Federal Republic of Nigeria 1999. Retrieved from http://www.nigeria-law. org/ConstitutionOfTheFederalRepublicOfNigeria.htm

Ford Foundation. (2011). Youth sexuality and rights. Retrieved from http://www.fordfoundationorg/2001-annual/youth-sexuality -and-rights/map/H/married-by-15/Nier

Girls Not Brides. (n.d.). Child marriage around the world: Nigeria. Retrieved from http://www.girlsnotbride.org/child-marriage/ nigeria/

International Center for Research on Women. (n.d.). Child marriage. Retrieved from http://www.icrw.org/what-we-do/adolescent/ child-marriage

Oduah, C. (2013). Facing child marriage in Nigeria. Retrieved from http://www.hufingtonpost.com/chika-oduah/child-marriage -nigeria

Okafor, U. (2014). The practice of child marriage in Nigeria. Retrieved April 13, 2015, from http://www.huffingonpost.com/ udoka-okafor/the-practice-of-child-marriage

Olasode, O. A., Olaogun, A. A., Fatusi, O. A., \& Mosaku, S. K. (2008). Women's health, a growing multidisciplinary challenge in Africa: A review. African journal of Gender and Development, 1(1).

Organization of African Unity. (1999). African charter on the rights and welfare of the child. Retrieved from http://www.au.int/en/sites/default/files/Charter_En_African_Charter_on_the_Rights_and_Wlefare_of_the_Child_AddisAbab a_July1990.pdf 
Policy and Legal Advocacy Centre. (2003). Child's right act. Retrieved from http://www.placng.org/new/laws/C50.pdf

Population Council. (1995, September 4-15). Accelerating girls' education: A priority for governments. Fact sheet compiled for The Fourth World Conference on Women, Beijing.

Population Council. (2004). Child marriage briefing on Nigeria. Retrieved from http://www.popcouncil.org

United Nations. (1948). Universal declaration of human rights. Retrieved from http://www.un.org/en/documents/udhr/index.shtml United Nations International Children's Emergency Fund (UNICEF). (2001). Early marriage, child spouse. Retrieved from http://www.unicef-ifc.org/publications/pdf/digest/e.pdf

UNICEF. (2012). A note on child marriage. Retrieved from http://www.unicef.org/policyanalysis/files/Noteonchildmarriage.pdf

UNICEF. (2013). State of the worlds children:Children with disabilities. Retrieved from http://www.unicef.org/sowc2013/

UNICEF. (2014). Child marriage. Retrieved from http://www.unicef.org/protection/57929_58008.html

United Nations Fund for Population Activities (UNFPA). (2012). Marrying too young: End child marriage. Retrieved from http://www.refworld.org/docid/508fe73f2.html

United Nations Human Rights. (1989). Convention on the rights of the child. Retrieved from http://www.ohchr.org/en/profession alinterest/pages/crc.aspx

United Nations Population Fund. (2012). Child brides. Retrieved from http://www.economist.com/blogs/dailychart/2011/02/child _brides 